\title{
Can a global model reproduce observed trends in summertime surface ozone levels?
}

\author{
S. Koumoutsaris ${ }^{1, *}$ and I. Bey ${ }^{2}$ \\ ${ }^{1}$ International Space Science Institute, Bern, Switzerland \\ ${ }^{2}$ Center for Climate Systems Modeling, ETH Zurich, Zurich, Switzerland \\ *now at: Risk Management Solutions, EC3R 8NB, London, UK
}

Correspondence to: S. Koumoutsaris (koumoutsaris@issibern.ch)

Received: 23 December 2011 - Published in Atmos. Chem. Phys. Discuss.: 20 January 2012

Revised: 19 June 2012 - Accepted: 11 July 2012 - Published: 2 August 2012

\begin{abstract}
Quantifying trends in surface ozone concentrations is critical for assessing pollution control strategies. Here we use observations and results from a global chemical transport model to examine the trends (1991-2005) in daily maximum 8-h average concentrations in summertime surface ozone at rural sites in Europe and the United States (US). We find a decrease in observed ozone concentrations at the high end of the probability distribution at many of the sites in both regions. The model attributes these trends to a decrease in local anthropogenic ozone precursors, although simulated decreasing trends are overestimated in comparison with observed ones. The low end of observed distribution show small upward trends over Europe and the western US and downward trends in Eastern US. The model cannot reproduce these observed trends, especially over Europe and the western US. In particular, simulated changes between the low and high end of the distributions in these two regions are not significant. Sensitivity simulations indicate that emissions from far away source regions do not affect significantly summer ozone trends at both ends of the distribution in both Europe and US. Possible reasons for discrepancies between observed and simulated trends are discussed.
\end{abstract}

\section{Introduction}

Quantifying surface ozone $\left(\mathrm{O}_{3}\right)$ concentrations and associated trends is critical for understanding the processes influencing tropospheric $\mathrm{O}_{3}$ budget and assessing pollution control strategies (Lin et al., 2000; Vingarzan, 2004). Longterm trends in tropospheric $\mathrm{O}_{3}$ are however difficult to in- fer due to their large natural variability and to the scarcity of long records of reliable ozone measurements (Staehelin and Weiss, 2001; Oltmans et al., 2006; IPCC, 2007). Even the sign and magnitude of long-term tropospheric $\mathrm{O}_{3}$ trends (as well as the causes of these changes) can differ significantly between nearby locations (Oltmans et al., 2006; Logan et al., 2012). Although current trends are not geographically uniform, recent studies report declining trends in $\mathrm{O}_{3}$ concentrations at urban sites and at sites downwind of urban centers in North America and Europe (Vingarzan, 2004; Martien and Harley, 2006; Logan et al., 2012; Wilson et al., 2012, and references therein). These declines are more evident at the high end of the ozone probability distribution and appear to be associated with declining local ozone precursor emissions (Bronnimann et al., 2002; Vingarzan, 2004; Jonson et al., 2006; Logan et al., 2012). In contrast, increasing trends are often seen for values at the mid and low end of the distribution and are likely related with increasing trends in background ozone (i.e., ozone not resulting directly from local emissions) (Lin et al., 2000; Jonson et al., 2006). The origins of this increase in ozone background are still unclear (Bronnimann et al., 2002; Jonson et al., 2006) but some of the plausible factors include changes in ozone precursor emissions with subsequent long range transport, change in stratospheric-tropospheric exchange, and global rise in methane levels (Lin et al., 2000; Vingarzan, 2004; Jonson et al., 2006; Ordóñez et al., 2007; Fiore et al., 2009).

The objectives of this study are to assess the ability of a state-of-the-art global chemical transport model to reproduce observed trends in surface ozone and to quantify the contribution of emissions from distant sources over Europe and 

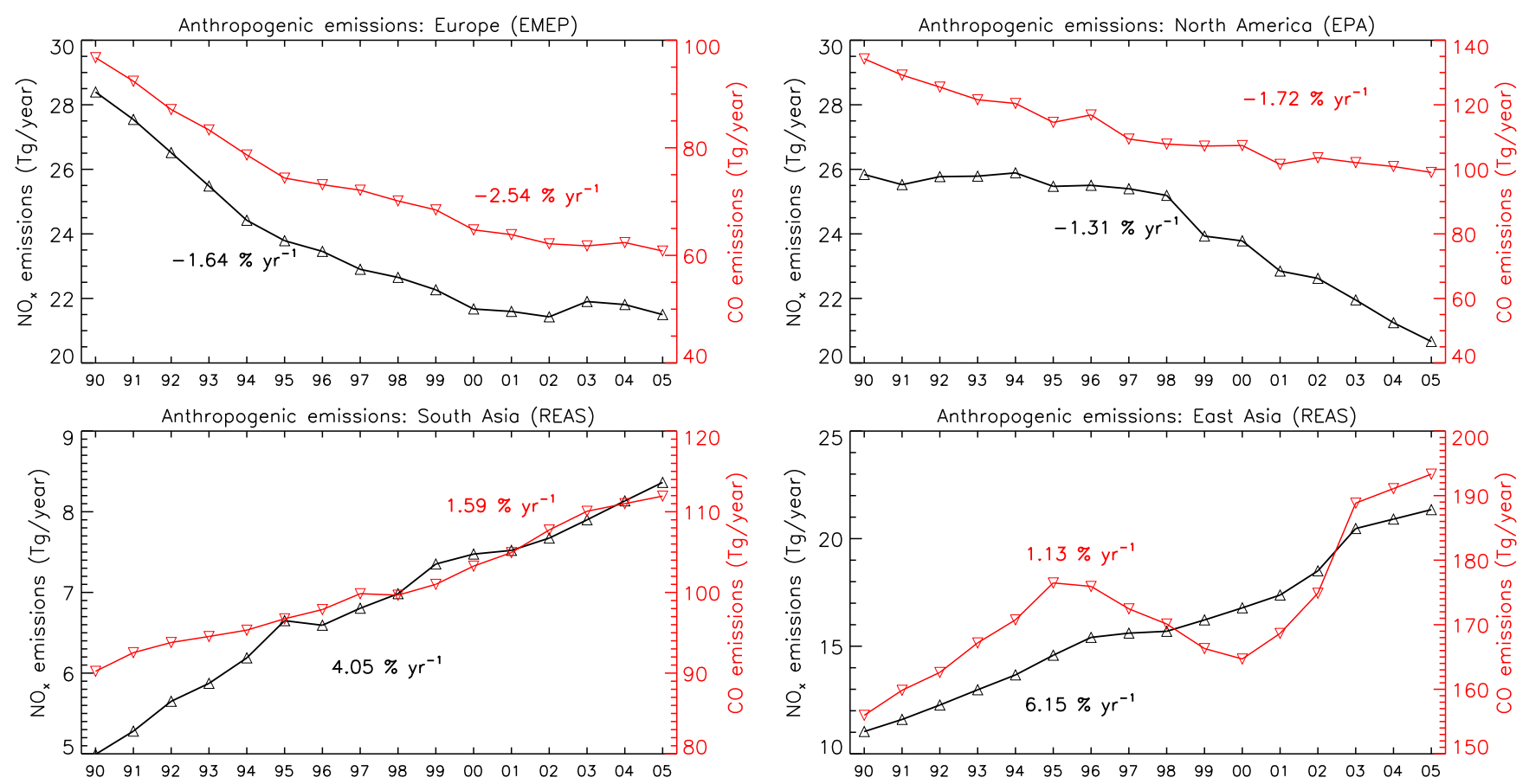

Fig. 1. Interannual (from 1990 to 2005) anthropogenic emissions of $\mathrm{NO}_{\mathrm{x}}$ (in black) and $\mathrm{CO}$ (in red) implemented in the GEOS-Chem model over four important anthropogenic source regions: Europe, North America, South Asia, and East Asia.

North America. We focus over the summer season when sunshine drives $\mathrm{O}_{3}$ levels above air pollution regulations defined by environmental protection agencies. Even though longrange transport in the Northern Hemisphere is minimal in summer, it can influence ground-level $\mathrm{O}_{3}$ limit exceedances in this season (Fiore et al., 2002; Wang et al., 2009; Hogrefe et al., 2011). We compare observed and simulated changes in probability distribution of daily maximum 8-h average summer $\mathrm{O}_{3}$ concentration for a period from 1991 to 2005. Hourly observations from the European Monitoring and Evaluation Programme (EMEP) (EMEP, 2008), the World Data Centre for Greenhouse Gases (WDCGG) (WMO, 2008), and the Clean Air Status and Trends Network (CASTNET) (EPA, 2007) were used, conjointly with results from a 15 -yr simulation performed with the global chemistry transport model GEOS-Chem (Koumoutsaris et al., 2008). A brief description of the model, emission inventory and simulations used in this study is given in Sect. 2. The methods used to compute the observed and simulated trends are presented in Sect. 3. Results for Europe and United States (US) are shown in Sect. 4 and are further discussed in Sect. 5.

\section{The GEOS-Chem model}

We use the GEOS-Chem model, a global chemical-transport model driven by assimilated meteorological data from the Data Assimilation Office NASA Global Modeling and Assimilation Office of NASA (Bey et al., 2001). The work shown here employed the version v7-03-06 of GEOSChem (http://www.as.harvard.edu/chemistry/trop/geos) that is driven by the GEOS-4 assimilated meteorological observations. The GEOS-4 dataset has a temporal resolution of $6 \mathrm{~h} \mathrm{(} 3 \mathrm{~h}$ for surface variables and mixing depths), a horizontal resolution of $1^{\circ} \times 1.25^{\circ}$, and 55 layers in the vertical from the surface up to $0.01 \mathrm{hPa}$. We degrade the horizontal resolution to $2^{\circ} \times 2.5^{\circ}$ and 30 layers in the vertical. The model configuration used in this study is similar to that reported in Koumoutsaris et al. (2008), except for the $\mathrm{O}_{3}$ precursor emissions which are described below.

\subsection{Ozone precursor emissions}

Anthropogenic emissions of trace gases are based on an emission inventory for 1985 described by Wang et al. (1998b), that includes $\mathrm{NO}_{\mathrm{x}}$ emissions from the Global Emission Inventory Activity (GEIA) (Benkovitz et al., 1996), nonmethane hydrocarbon (NMHC) emissions from Piccot et al. (1992), and CO emissions from Duncan et al. (2007), scaled until 1998, as described in Bey et al. (2001). We further implemented interannual varying emissions over the most important anthropogenic source regions. More precisely, we implemented the European Monitoring and Evaluation Program (EMEP) Expert emissions (Vestreng et al., 2006) over the European continent. During the period from 1990 to 2005, EMEP emissions show a strong decrease over Europe $\left(35^{\circ} \mathrm{N}-65^{\circ} \mathrm{N}, 10^{\circ} \mathrm{W}-40^{\circ} \mathrm{E}\right)$, as shown in Fig. $1(-1.6 \%$ per year for $\mathrm{NO}_{\mathrm{x}}$ and $-2.7 \%$ per year for $\mathrm{CO}$ ). Trends in 
Table 1. Simulations performed with the GEOS-Chem model in the present work.

\begin{tabular}{lrl}
\hline Name & Period & Configuration \\
\hline \multicolumn{2}{l}{ Control simulation } & \\
S0 & 1991-2005 & All parameters vary interannually \\
\hline \multicolumn{2}{l}{ Sensitivity simulations } & \\
SEur & $2001-2005$ & European anthropgenic emissions fixed in 1990 \\
SNam & $2001-2005$ & North American anthropgenic emissions fixed in 1990 \\
SSAs & $2001-2005$ & South Asian anthropgenic emissions fixed in 1990 \\
SEAs & $2001-2005$ & East Asian anthropgenic emissions fixed in 1990 \\
SXEur & $2001-2005$ & North American, East and South Asian anthropgenic \\
& & emissions fixed in 1990 and Methane concentrations fixed in 1990. \\
SMET & $2001-2005$ & Meteorology of 10 years before (i.e. 1991-1995) \\
SBB & $2001-2005$ & Climatology \\
\hline
\end{tabular}

emissions for certain volatile organic compounds (VOCs) (propene, butane, ethane, methyl-ethyl-ketone and acetaldehyde) were also implemented. For the US, we use the Environmental Protection Agency (EPA) National Emissions Inventory (NEI) 1999 v.1 inventory (NEI99, http://www.epa. gov/ttn/chief/net/1999inventory.html), with some modifications as described in Hudman et al. (2007), which we scale with the NEI Emissions trends data provided by the EPA (EPA, 2007). Notice however that the scaling is applied uniformly all over the US and to all VOCs. Emissions from Canada and Mexico are not varying after 1998, but they account together for less than $10 \%$ of the US emissions (Wang et al., 2009). Figure 1 shows the year-to-year variation in $\mathrm{NO}_{\mathrm{x}}$ and $\mathrm{CO}$ anthropogenic emissions over North America $\left(125^{\circ} \mathrm{W}-60^{\circ} \mathrm{W}, 15^{\circ} \mathrm{N}-55^{\circ} \mathrm{N}\right)$ for the period from 1990 to 2005. The trends in $\mathrm{NO}_{\mathrm{x}}$ and $\mathrm{CO}$ emissions are $-1 \%$ and $-1.7 \%$ per year, respectively. For Asia, we implemented the Regional Emission Inventory in Asia (REAS) (Ohara et al., 2007) for $\mathrm{NO}_{\mathrm{x}}, \mathrm{CO}$ and VOCs (propene, propane, butane, ethane, methyl-ethyl-ketone). Data are available from 1990 to 2005, however, the last two years (2004 and 2005) are "predictions" (Ohara et al., 2007) and show lower interannual variability. The interannual variability in emissions for South Asia $\left(50^{\circ} \mathrm{E}-95^{\circ} \mathrm{E}, 5^{\circ} \mathrm{N}-35^{\circ} \mathrm{N}\right)$ and East Asia $\left(95^{\circ} \mathrm{W}-160^{\circ} \mathrm{W}, 15^{\circ} \mathrm{N}-50^{\circ} \mathrm{N}\right.$ ) is shown in Fig. 1 (bottom panels). Anthropogenic emissions strongly increase in East Asia from 1990 to 2005, especially for $\mathrm{NO}_{\mathrm{x}}(5.8 \%$ per year). The decrease of CO emissions from 1995 to 2005 is due to a reduction in consumption of coal and biofuel in the domestic sector during this period. This leads to a smaller $\mathrm{CO}$ trend of $1 \%$ per year. South Asian emissions also increase significantly during our study period $\left(3.2 \%\right.$ per year for $\mathrm{NO}_{\mathrm{x}}$ and $1.5 \%$ per year for $\mathrm{CO}$ ). Ship emissions are accounted in the model only in the eastern Atlantic and the Indian ocean as part of the EMEP and REAS inventories, respectively. Recent studies, however, support that the effects of international shipping over the European continent are rather small (Jonson et al., 2006). Finally, we have also implemented a $+3 \%$ annual increment of global $\mathrm{NO}_{\mathrm{x}}$ aircraft emissions $(0.5 \mathrm{Tg} \mathrm{N}$ in 1992) following IPCC (1999) and EPA (2000) reports.

Soil $\mathrm{NO}_{\mathrm{x}}$ emissions $(\sim 5.9 \mathrm{Tg} \mathrm{N}$ per year) are calculated according to the Yienger and Levy (1995) algorithm with the canopy reduction factor described in Wang et al. (1998a). Biomass burning emissions are derived from an inventory of total annual biomass burned described in Lobert et al. (1999) and Duncan et al. (2003). Annual biomass burned is converted to $\mathrm{NO}_{\mathrm{x}}$ emissions by applying emission factors, providing a climatological inventory for biomass burning emissions, as described in Duncan et al. (2003). Interannual variations are further accounted for using the TOMS Aerosol Index product (Torres et al., 1998; Herman et al., 1997; Hsu et al., 1996) from January 1987 to July 1996 following Duncan et al. (2003) and the Advanced Along Track Scanning radiometer (AATSR) active fire dataset (Arino and Melinotte, 1995) from August 1996 to 2005 following Generoso et al. (2003) with slight improvements given in Koumoutsaris et al. (2008). The global annual biomass burning emissions range from 5 to $8 \mathrm{Tg} \mathrm{N}$ during our study period. Emissions of $\mathrm{NO}_{\mathrm{x}}$ from lightning ( $\sim 6 \mathrm{Tg} \mathrm{N}$ per year) are linked to deep convection following the parametrization of Price and Rind (1992) with vertical profiles from Pickering et al. (1998) as implemented by Wang et al. (1998b).

\subsection{Simulations}

We first performed a 15-yr control simulation (labelled "S0") from January 1991 to December 2005. We then carried out four sensitivity simulations from 2001 to 2005 with anthropogenic emissions of specific geopolitical regions - including Europe ("SEur"), North America ("SNAm"), South Asia ("SSAs"), and East Asia ("SEAs") - set to the year 1990 (see also Table 1). An additional sensitivity simulation ("SXEur") was performed with anthropogenic emissions over North America, South and East Asia, and methane concentrations fixed to the 1990 levels to assess their combined impact on European ozone levels. The role of changing biomass burning emissions is examined using a sensitivity simulation 
Table 2. Model performance metrics for the daily maximum 8-h average summer $\mathrm{O}_{3}$ concentration at all available sites for 1991-2005 for 5 percentiles. Column a: the three numbers correspond to the number of sites with correlation coefficient lower or equal to 0.3 , between 0.3 and 0.7 , and greater than or equal to 0.7 , respectively. Column b: The mean bias is calculated for each site and then averaged to display in this table. Results are shown separately for sites in Europe and US.

\begin{tabular}{lcc}
\hline \multicolumn{1}{c}{ Percentile } & (a) & (b) \\
Europe -43 sites & $R \leq 0.3,0.3<R<0.7, R \geq 0.7$ & Mean bias, ppb (\%) \\
\hline 5th & $20,21,2$ & \\
20th & $14,19,10$ & $-7.2(-20.7 \%)$ \\
50 th & $4,27,12$ & $-2.7(-10.0 \%)$ \\
80th & $3,17,23$ & $-0.9(-4.2 \%)$ \\
95th & $2,17,24$ & $1.6(0.5 \%)$ \\
\hline USA - 38 sites & & $5.3(6.2 \%)$ \\
\hline 5th & $21,15,2$ & \\
20th & $5,13,20$ & $-16.1(-66.2 \%)$ \\
50 th & $1,13,24$ & $-15.0(-36.2 \%)$ \\
80th & $0,10,28$ & $-13.9(-26.9 \%)$ \\
95 th & $4,25,9$ & $-10.9(-17.4 \%)$ \\
\hline
\end{tabular}

with biomass burning emissions set to climatological values ("SBB"). Finally, we performed an additional simulation ("SMet") using emissions for the 2001-2005 period but meteorological fields from 1991-1995 to examine the impact of changing meteorology.

\section{Method}

We used hourly $\mathrm{O}_{3}$ data available from the EMEP, WDCGG, and CASTNET databases to compute the daily summer (June-July-August) maximum 8-h average $\mathrm{O}_{3}$ concentration (according to the EPA regulations (EPA, 1998) and named as "8h-max $\mathrm{O}_{3}$ ", hereafter) at several sites over Europe and the US. We only used the sites with at least 30 days of data in summer for each year from 1991 to 2005. There are 43 sites in Europe and 38 sites in the US that meet these criteria. For each site, we examined the linear trends of several percentile populations as shown for example for Illmitz (Austria) in Fig. 2. The location of the sites and the observed and simulated trends at the 5th and 95th percentile are presented in Figs. 3 and 4 for Europe and the US, respectively.

We next computed the cumulative probability distribution (CPD) of the 8h-max $\mathrm{O}_{3}$ concentrations aggregated over the ensembles of stations for Europe (Fig. 5) and for US (Fig. 6). We compared the distributions at both observed and simulated $\mathrm{O}_{3}$ concentrations at the beggining (19911994) and at the end (2001-2005) of the record. We used 5 -yr periods in order to reduce the effect of interannual variability associated with meteorology. However, we excluded the year 2003 which was particular anomalous (heat wave) over Europe (Schär et al., 2004; Wilson et al., 2012). The statistical significance of the difference between the two distributions is determined by comparing the populations

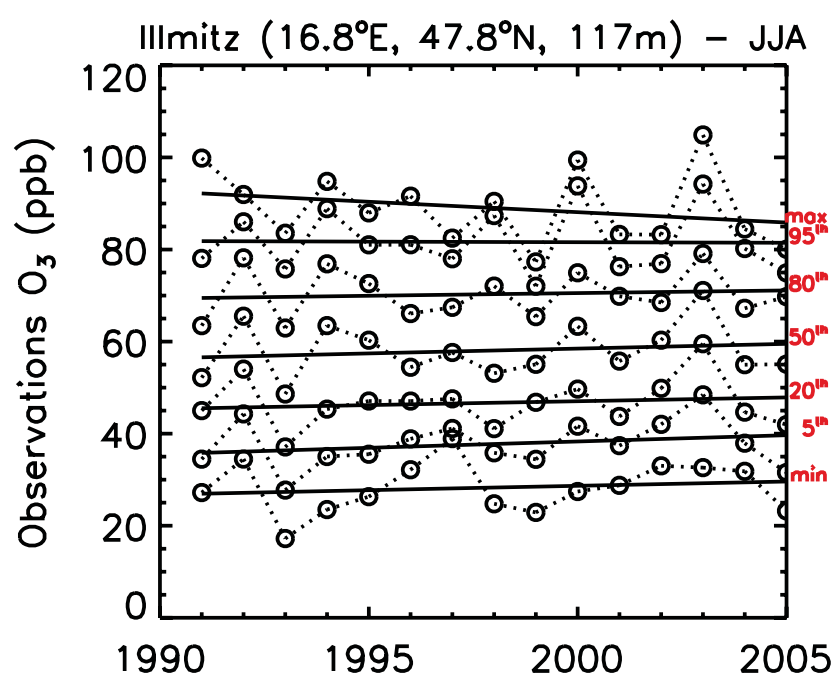

Fig. 2. Observed interannual (from 1990 to 2005) variation (dotted lines) and linear trends (solid lines) in several percentile populations of the summertime $\mathrm{O}_{3}$ concentrations for the station of Illmitz, in Austria.

at several percentiles (5th, 10th, 20th, etc.) with the twosided Kolmogorov-Smirnov statistic test following Lin et al. (2000).

\section{Observed and simulated ozone trends}

\subsection{Europe}

The ability of the GEOS-Chem model to simulate the interannual variation in $\mathrm{O}_{3}$ concentrations at the northern midlatitudes was discussed in a previous study (Koumoutsaris 


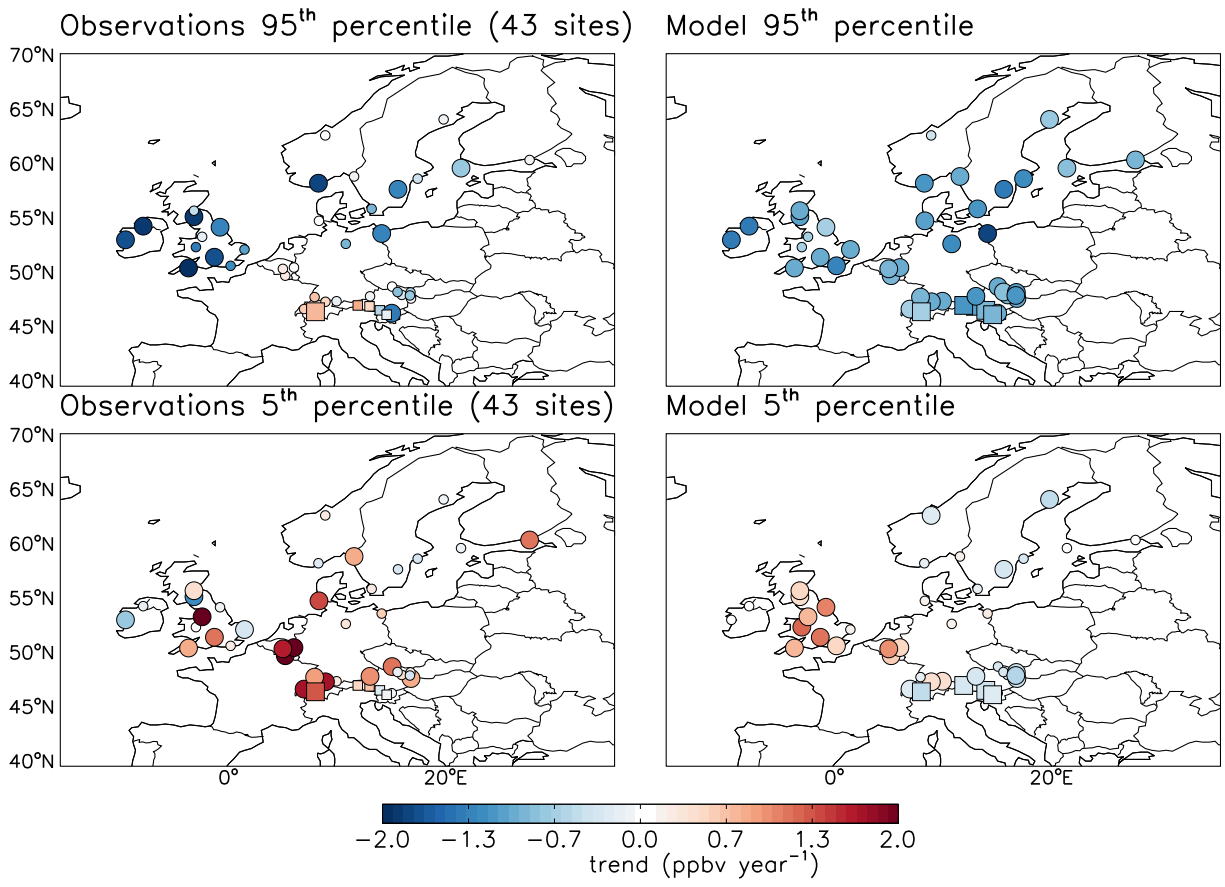

Fig. 3. Trends $\left(\% \mathrm{yr}^{-1}\right)$ in the 95 th (top) and 5 th (bottom) percentile of the distribution of the 8 -h daily maximum summertime $\mathrm{O}_{3}$ concentrations at 43 European stations for the observations (left) and the model (right). The simulated trends (right panels) are computed using the hourly model $\mathrm{O}_{3}$ values from the control simulation ("S0"). Circles and squares denote trends at sites above and below $1500 \mathrm{~m}$, respectively. Large symbols denote significant trends at the 0.05 level. Small symbols denote trends that are not statistically significant.

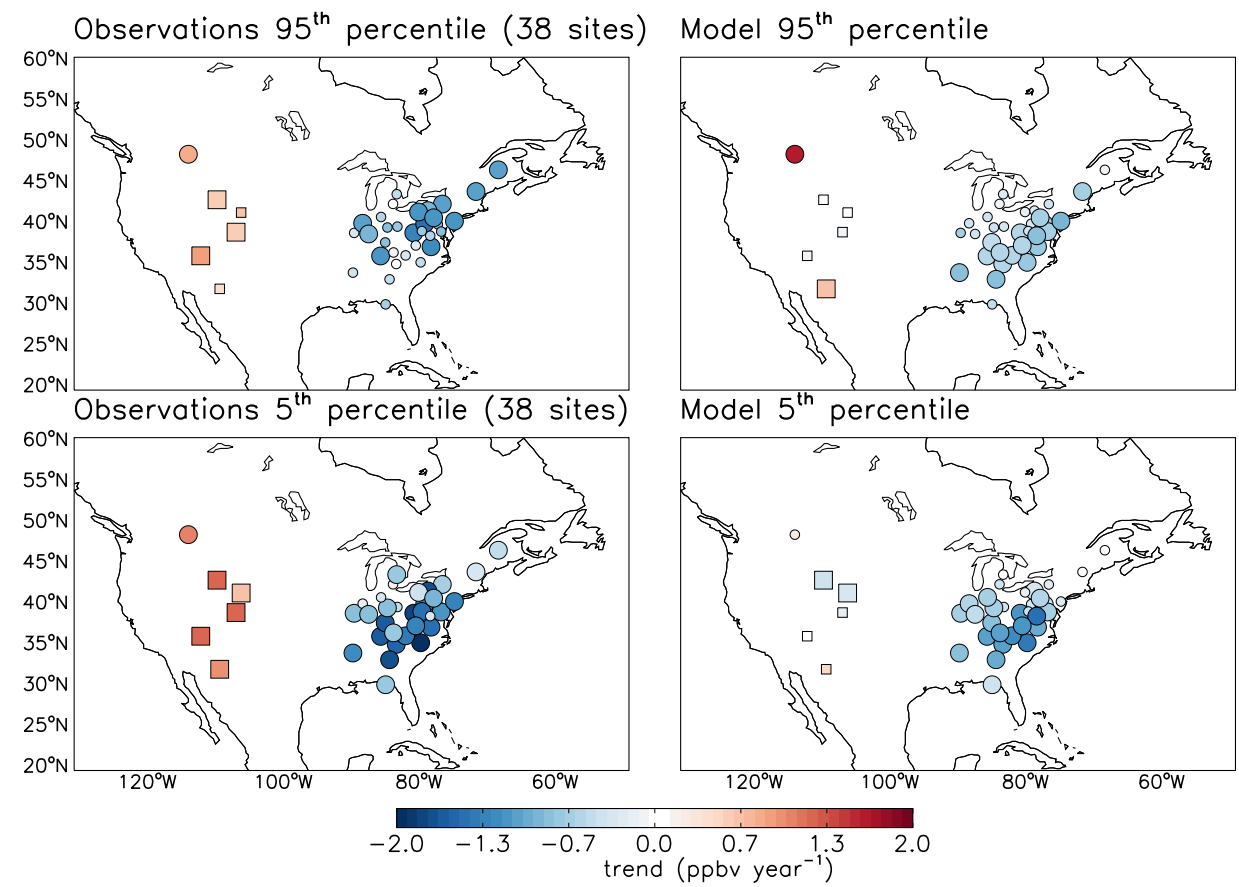

Fig. 4. Trends $\left(\% \mathrm{yr}^{-1}\right)$ in the 95 th (top) and 5 th (bottom) percentile of the distribution of the 8-h daily maximum summertime $\mathrm{O}_{3}$ concentrations at 38 US stations for the observations (left) and the model (right). Circles and squares denote trends at sites above and below $1500 \mathrm{~m}$, respectively. Large symbols denote significant trends at the 0.05 level. Small symbols denote trends that are not statistically significant. 

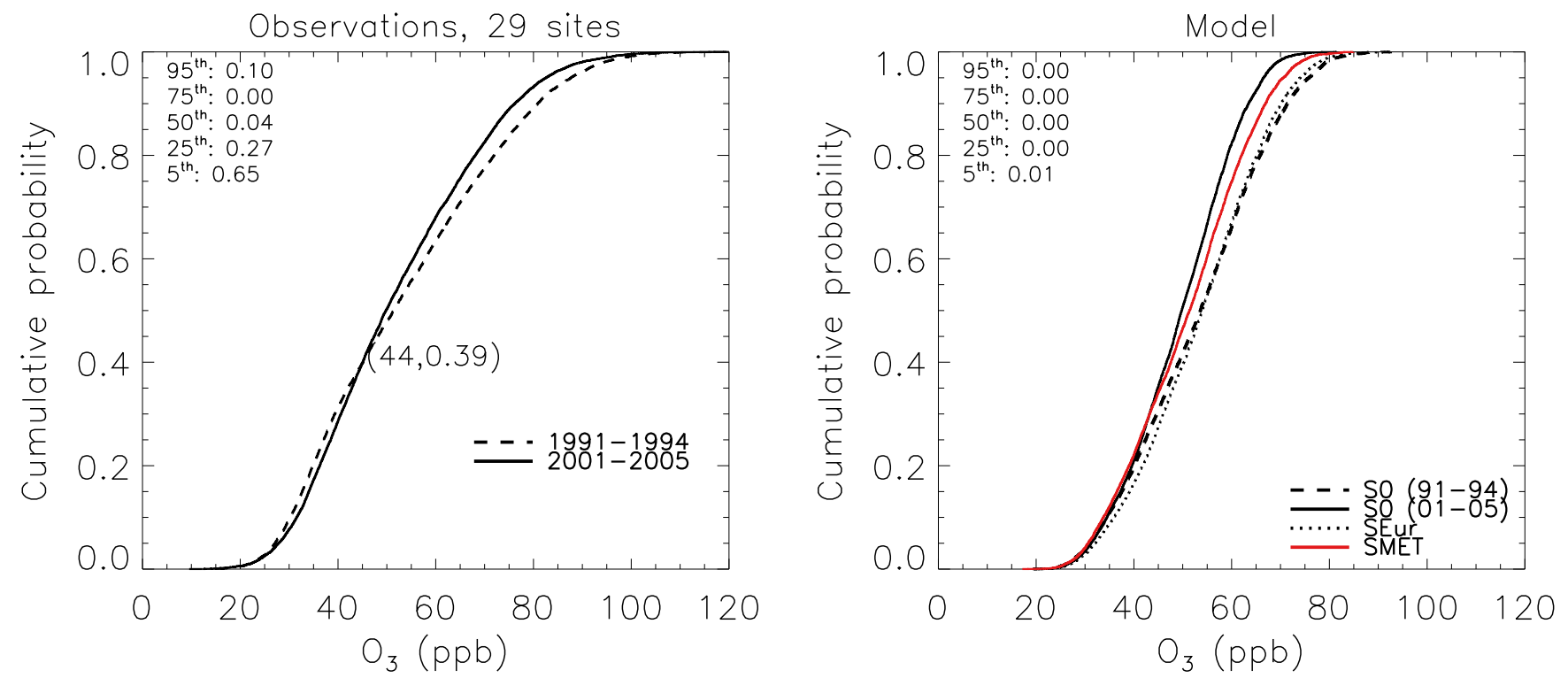

Fig. 5. Cumulative probability distribution of the 8-h daily maximum summertime (JJA) $\mathrm{O}_{3}$ concentrations at rural sites in Europe in 19911994 (dashed line) and 2001-2005 (solid line). We exclude the anomalous hot year 2003 and also the sites with titration effects (see Sect. 4.1 .1 for details). The statistical significance level between the two distributions (1991-1994 vs. 2001-2005) is indicated for 5 percentiles in the upper left corner of each panel. The sensitivity simulations "SEur" (dotted line) and "SMet" (red line) are significantly different from "S0".

et al., 2008). It was found that the model is able to capture some of the large variations (e.g. the 1998-1999 anomaly) but that it has difficulty in representing the observed interannual variability in $\mathrm{O}_{3}$ at several sites. Koumoutsaris et al. (2008) argued that this may be related to a poor representation of stratospheric chemistry and dynamics (among other factors). The model's ability to represent surface summer $\mathrm{O}_{3}$ is shown in Table 2 which compares simulated and observed ozone for the period 1991 to 2005 at different percentiles. In the majority of the European sites, the agreement at the lower percentiles is very low with almost $50 \%$ of the sites presenting correlation coefficients lower than 0.3 . The model reproduces better $\mathrm{O}_{3}$ at the high percentiles, with more than $55 \%$ of the sites showing a correlation larger or equal to 0.7 at the 95th percentile. The fact that the model's performance decreases in a majority of sites at the low end of the distribution, where $\mathrm{O}_{3}$ is more inflenced by background concentrations, will be further discussed in the following sections. The mean bias between the model and the observations is relatively low with best performace at the median concentrations. The model (under-) over-estimate of $\mathrm{O}_{3}$ concentrations at the (high) low end of the distribution may be partly due to the relatively coarse model resolution which prevents the model from capturing the very high and the very low events.

The observed and simulated summer $\mathrm{O}_{3}$ trends at the 95th and 5th percentiles are shown in Fig. 3 (see also tables with the values at each site in the Appendix). The observed 8hmax $\mathrm{O}_{3}$ trends in Europe show large variability even between nearby sites but we find decreasing (increasing) concentrations at the high (low) end of the distribution on a quali- tative basis. Note that trends were computed for the period from 1991 to 2005 and that different values could be found if one considers slightly shorter or longer periods (Logan et al., 2010).

\subsubsection{Low percentiles}

Positive trends are found in the observations at several sites although only a few are statistically significant (Fig. 3). The increase in $\mathrm{O}_{3}$ concentrations at the low end of the distribution has been suggested to be related to an increase in background $\mathrm{O}_{3}$ concentrations, especially at high mountain sites, which are considered more representative of background conditions (Cristofanelli and Bonasoni, 2009). Nevertheless, even between high mountain sites, there are differences in the observed trends (Fig. 3) that may be related to e.g., local wind systems (Zellweger et al., 2000). Cui et al. (2011) found for example that summer convective boundary layer can reach the altitudes of Jungfraujoch during highpressure conditions (resulting in high ozone concentrations in 2003), which could balance the effect of a decrease in European precursor emissions.

The aggregated observations over the ensemble of stations are shown in the left panel of Fig. 5. The low tail of the observed CPD shows small but insignificant at the 0.05 level changes between 1991-1994 and 2001-2005 in the summer $8 \mathrm{~h}$-max $\mathrm{O}_{3}$ levels even though there is a qualitative change in observed $\mathrm{O}_{3}$ trends between the low and high percentiles. Note that the change in the CPD is not significant even if we 
consider only the high altitude sites of central Europe (not shown).

In the northwestern part of Europe (e.g., UK and western Europe), the model simulates upward trends at most of the sites (Fig. 3). This is also seen in the observations for some of these sites. In fact, Jenkin (2008) found that many of the UK sites are affected by local pollution episodes from upwind sources even though they are referred to as rural. In addition, Jenkin (2008) attributed the observed upward trends in the low $\mathrm{O}_{3}$ percentiles at these sites to reduced titration by $\mathrm{NO}$ (resulting from decreasing $\mathrm{NO}_{\mathrm{x}}$ emissions). Titration by NO could be a problem when interpreting long-term trends at lower ends of $\mathrm{O}_{3}$ probability distribution (Lin et al., 2000). We thus examined the NO titration effect by computing the ratio between the simulated $8 \mathrm{~h}-\mathrm{max} \mathrm{O}_{3}$ and the simulated hourly total reactive nitrogen $\left(\mathrm{NO}_{\mathrm{y}}=\mathrm{NO}+\mathrm{NO}_{2}+\right.$ $\mathrm{NO}_{3}+\mathrm{HNO}_{2}+\mathrm{HNO}_{3}$ ) for each station following the results of Sillman (2002) who reported that locations dominated by $\mathrm{NO}_{\mathrm{x}}$ titration have low values of $\mathrm{O}_{3} / \mathrm{NO}_{\mathrm{y}}$. Such low values are found during several days in summer in the early 1990s at most of the northwestern stations of Europe (3 Belgium sites, 3 northern German sites, and all (9) sites in the United Kingdom except the ones in Ireland) but do not occur in the later period of our study (2000-2005) as a result of pollution control measures and decreasing $\mathrm{NO}_{\mathrm{x}}$ emissions. We therefore excluded these sites when aggregating all observed and simulated data (Fig. 5).

At the remaining sites (e.g., central Europe), the model has also difficulties in reproducing the observed trends. Decreasing $\mathrm{O}_{3}$ concentrations are simulated at most of the central and northern sites while small but upward trends are observed. Possible reasons for the discrepancies between model and observations are discussed in Sect. 5.

\subsubsection{High percentiles}

At the high end of the distribution (top panels in Fig. 3), observations show declining $8 \mathrm{~h}$-max $\mathrm{O}_{3}$ concentrations at most of the sites, although only few of them (8 among 43) are significant at the 0.05 level. Upward trends are however seen over some stations in central Europe, e.g. Jungfraujoch in Switzerland and Vezin in Germany. The only station with statistically significant upward trend is Jungfraujoch $\left(0.69 \pm 0.58 \mathrm{ppbv} \mathrm{yr}^{-1}\right.$ at the 95 th percentile) which is located at $3758 \mathrm{~m}$ a.s.l. The model, in contrast, shows significant downward trends at most of the European sites.

Above $\sim 44$ ppbv, the observations show lower concentrations in 2001-2005 in comparison to 1991-1995 (Fig. 5). The difference between the two observed distributions is significant to the 0.05 level above the 40th percentile (not shown). The model (right panel of Fig. 5) shows similar behaviour, but the decrease in surface $8 \mathrm{~h}-\mathrm{max} \mathrm{O}_{3}$ concentrations between the two periods is overestimated by 4 5 ppbv. Sensitivity model simulations indicate that the simulated downward trends at the high end of the distribution is mainly related to the decrease in European emissions during this period (Fig. 5). Meteorology is also found to contribute significantly to the decrease in surface $\mathrm{O}_{3}$ according to the modeling results (simulation "SMet"). We performed several additional sensitivity simulations to examine the influence of individual parameters, such as temperature, clouds, UV radiation, horizontal and vertical winds, and planetary boundary layer height. None of the $\mathrm{O}_{3}$ distributions obtained from these simulations was significantly different from the control run, which suggests that a combination of different parameters (rather than a single one) influences surface $\mathrm{O}_{3}$ concentrations.

\subsection{United States}

The correlation between observed and modeled 8h-max $\mathrm{O}_{3}$ is somewhat better at the US sites (Table 2) than at the European sites but the mean bias is much higher, especially at the low percentiles. Similarly to Europe, the correlations are lower at the low percentiles for most of the sites. The model represents much better the high percentiles both in terms of interannual variation and bias in all investigated sites, as also noted for the European sites.

Figure 4 compares the observed and simulated 8h-max $\mathrm{O}_{3}$ trends at the 5th and 95th percentile for the CASTNET stations. A clear longitudinal difference is seen in the observations with increasing trends at the western mountainous sites and strong decreasing trends at most of the eastern sites. The model reproduces the contrasted geographical feature in the trends although it underestimates significantly their magnitude in the western part. Due to the large differences between these two regions, we discuss separately the eastern (east of $100^{\circ} \mathrm{W}$ ) and the western (west of $100^{\circ} \mathrm{W}$ ) sites in the following.

\subsubsection{Eastern sites}

Decreasing trends (significant at the 0.05 level) are observed at almost all the eastern sites at both high and low percentiles. The decrease in peak $\mathrm{O}_{3}$ concentrations is more pronounced in the north-eastern part of the region, a power plant dominated $\mathrm{NO}_{\mathrm{x}}$ source region, where emission controls have been succesfully implemented (Kim et al., 2006; Frost et al., 2006). The model reproduces the decreasing tends at all percentiles although it does not capture these largest ones, possibly because the trends in emission were applied uniformly over the US (see Sect. 2). According to the model sensitivity simulations (simulation "SNAm", Fig. 6), the decline in local emissions is responsible for the decreasing $\mathrm{O}_{3}$ trends and negligible influence was found from sources in Asia or Europe.

\subsubsection{Western sites}

In the western part, we found significant (at the 0.05 level) upward trends for the observed 8h-max $\mathrm{O}_{3}$ concentrations, 

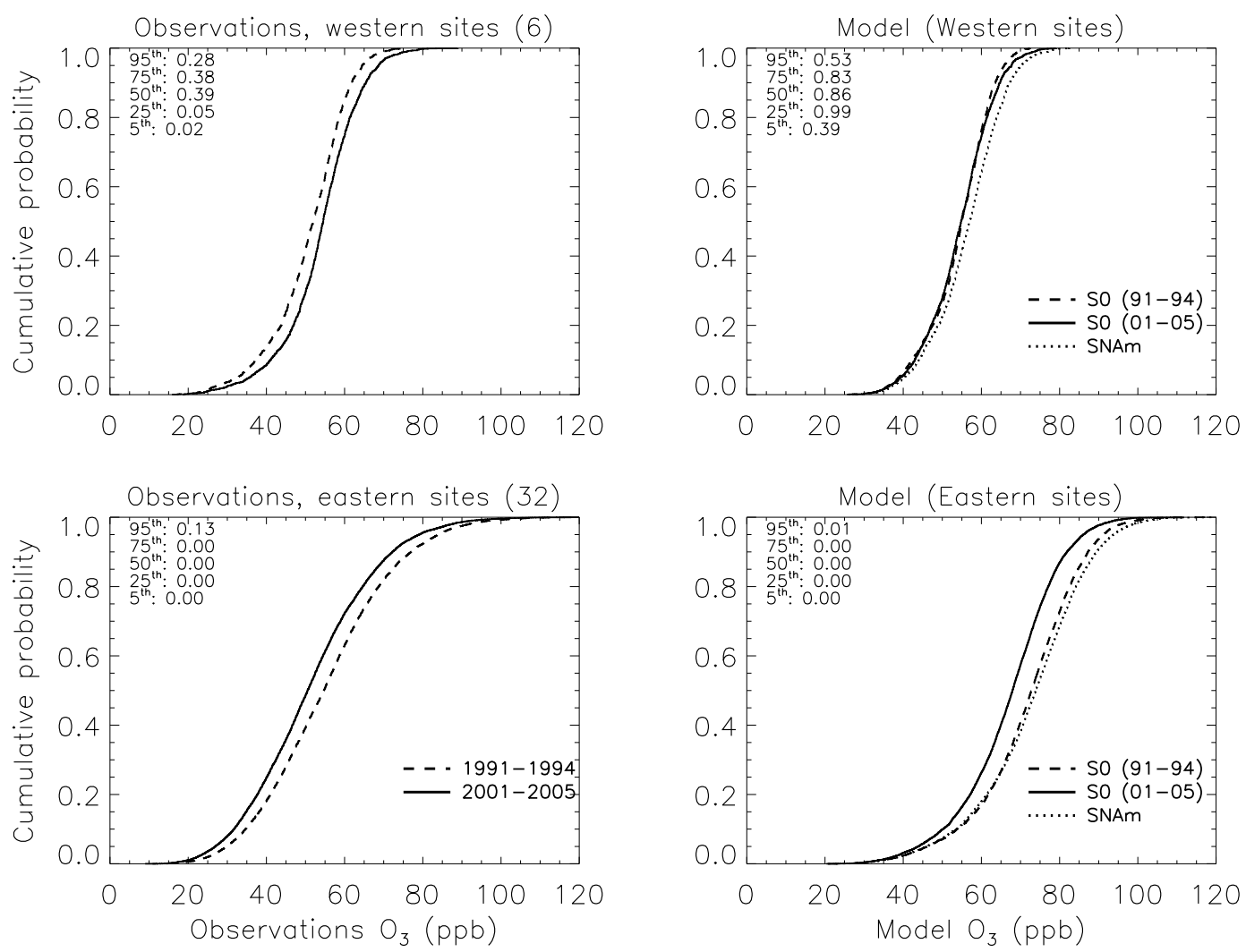

Fig. 6. Cumulative probability distribution of the 8-h daily maximum summertime (JJA) $\mathrm{O}_{3}$ concentrations at rural sites in the US in $1991-$ 1994 (dashed line) and 2001-2005 (solid line). For consistency with Europe, we exclude the year 2003. Top panels: western sites. Bottom panels: eastern sites (see text for details). Observations and model results are shown in the left and right panels, respectively. The statistical significance level between the two distributions (1991-1994 vs. 2001-2005) is indicated for 5 percentiles in the upper left corner of each panel. The sensitivity simulation "SNAm" (dotted line) is significantly different from "S0" (period 2001-2005).

with larger values at the low percentiles. The model underestimates significantly these trends (Fig. 4) with no significant difference between the two periods (Fig. 6). Part of the underestimate may originate from local pollution changes that are not captured in the model. There are some indications that $\mathrm{NO}_{\mathrm{x}}$ emissions have increased in urban areas of the western US in the 1990s (Parrish, 2006) before decreasing in the 2000s (Kim et al., 2009). However, emission trends in the 1990s are highly uncertain and vary considerably depending on the methods used to make those estimates (Parrish, 2006). Notice also that 5 among 6 of the western US sites are in mountain regions (above $1500 \mathrm{~m}$ asl) and thus more sensitive to Asian pollution because of their exposure to the free troposphere. It has been also suggested that increased wildfires in the later period (2000s) may also have contributed to the observed $\mathrm{O}_{3}$ increase (Jaffe et al., 2008; Jaffe, 2011). We further discuss this issue in the following section.

\section{Discussion}

We have shown in previous sections that the GEOS-Chem model has difficulties to simulate correctly the trends in $\mathrm{O}_{3}$ concentrations, in particular at the low percentiles and at mountain sites in both Europe and US. This probably reflects changes in background ozone concentrations that are not captured by the model. This appears to be a common feature in most modeling studies, which show lesser increases in background ozone during the 1990s than observations suggest, as also reported by Logan et al. (2010). Several processes have been suggested to possibly influence background ozone, including changes in long-range transport from Asia (Lin et al., 2000; Fiore et al., 2002; Naja et al., 2003; Jaffe et al., 2003), methane concentrations (Fiore et al., 2009), and contribution of stratospheric ozone (Ordóñez et al., 2007) as further discussed in the following.

\subsection{Long-range transport from Asia}

In summer, the transport from Asia occurs predominatly in warm conveyor belts of midlatitude cyclones, deep 


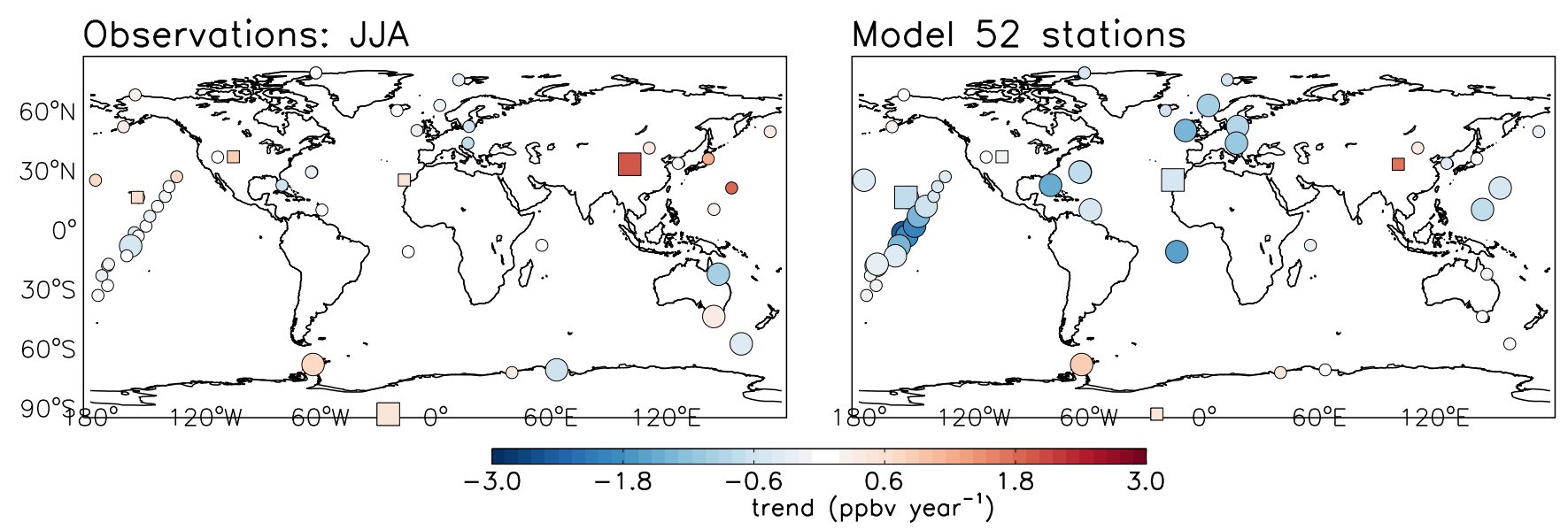

Fig. 7. Trends $\left(\% \mathrm{yr}^{-1}\right)$ in the summertime $\mathrm{CO}$ concentrations at 52 stations from the WDCGG network for the observations (left) and the model (right) for the period 1991-2005. Circles and squares denote trends at sites above and below $1500 \mathrm{~m}$, respectively. Large symbols denote significant trends at the 0.05 level. Small symbols denote trends that are not statistically significant.

convection, and in typhoons (Liang et al., 2007). A significant fraction of the summertime ouflow is also transported westwards to the Middle East with some possible implications for Europe (Liu et al., 2003; Auvray and Bey, 2005). $\mathrm{Xu}$ et al. (2008) and Ohara et al. (2008) found increasing $\mathrm{O}_{3}$ trends in all seasons at a background station in eastern China and in Japan, respectively, and attributed those to the increase in Chinese $\mathrm{NO}_{\mathrm{x}}$ emissions. The only East Asian site in the WDCGG data that meets our criteria (defined in Sect. 4.1) is Ryori, in Japan (not shown). The observations show upward trends from 1991 to 2005 in surface $8 \mathrm{~h}$-max $\mathrm{O}_{3}$ summer concentrations at all percentiles of the distribution. The model once again underestimates the observed trends. We found similar results for carbon monoxide concentrations (CO). We computed $\mathrm{CO}$ trends from monthly mean data from WDCGG and the model standard simulation (S0) (Fig. 7). The model underestimates the annual summer (JJA) trends in CO over the same period (1991 to 2005) at several sites over the globe. The model's inability to capture the trends in long-range transport over the Pacific may be related to the following points:

(a) An underestimate of Asian $\mathrm{O}_{3}$ precursor emission trends. Indeed, it has been suggested that the REAS emission inventory used in our study for Asia underestimates Asian $\mathrm{NO}_{\mathrm{x}}$ emissions and trends (Kurokawa et al., 2009; Uno et al., 2007). More precisely, Uno et al. (2007) compared the $\mathrm{NO}_{2}$ columns from satellite observations with the results from the CMAQ regional model fed with the REAS emission inventory and concluded that REAS most likely underestimates not only the magnitude over polluted industrial regions in Asia but also the rapid growth of the Chinese emissions during the period from 1996 to 2002. Kurokawa et al. (2009) also found that the REAS emissions underestimate the rate of increase in $\mathrm{NO}_{\mathrm{x}}$ emissions in July from 1996 to 2002, when compared with optimized emissions derived from data assimilation of satellite observations.

(b) An underestimate of Asian outflow and the associated chemical processes during transport. Our results show that the location and intensity of the Asian $\mathrm{O}_{3}$ transport have not significantly changed over the studied period. The fixed meteorology (SMet) simulation shows little influence in $\mathrm{O}_{3}$ trends at the western US sites (not shown). Although global transport models can reproduce the main features associated with long-range transport, several studies have also indicated that they exhibit difficulties in simulating the chemical processes inside the transport plumes (Kiley et al., 2003; Rastigejev et al., 2010). Liang et al. (2007) for example, found that the GEOS-Chem model captures the timing and location of the Asian plumes but significantly underestimates the magnitude of observed enhancements in $\mathrm{CO}$, $\mathrm{O}_{3}$, PAN and $\mathrm{NO}_{\mathrm{x}}$, during the INTEX-A campaing (July to August 2004). Zhang et al. (2008) also found $15 \%$ lower CO over the Pacific (INTEX-B aircraft campain) in spring for GEOS-Chem and attributed this to an overestimate in hydroxyl radical $(\mathrm{OH})$ in the model. At that stage, the extent to which this could affect the model's inability to reproduced the observed tropospheric $\mathrm{O}_{3}$ trends remains unclear.

\subsection{Change in methane concentrations}

Methane $\left(\mathrm{CH}_{4}\right)$, besides being an important greenhouse gas, is also a known major source of tropospheric $\mathrm{O}_{3}$. Changes in $\mathrm{CH}_{4}$ growth rate are not well understood, but could be related to changes in the sources and/or OH sink (Wuebbles and Hayhoe, 2002; Bousquet et al., 2006; Rigby et al., 2008). Our model uses annual and latitudinally prescribed observed $\mathrm{CH}_{4}$ concentrations. When $\mathrm{CH}_{4}$ concentrations are 
kept fixed to the 1990 levels, we find negligible contribution of changing $\mathrm{CH}_{4}$ concentrations on the 8h-max $\mathrm{O}_{3}$ summer trends.

\subsection{Change in biomass burning emissions}

It has been suggested that biomass burning can also influence $\mathrm{O}_{3}$ trends in specific regions (Jaffe et al., 2004; Simmonds et al., 2005). However, fires in the Northern Hemisphere are mostly of natural origin (over two thirds are ignited naturally by lightning) and show a large interannual variability, which makes their trends difficult to assess (Giglio et al., 2010). The influence of fires on $\mathrm{O}_{3}$ over Europe is highly episodic and not well quantified (Logan et al., 2012). Our model shows negligible influence of biomass burning emissions in $\mathrm{O}_{3}$ changes between the early 2000s and early 1990s. O ${ }_{3}$ changes in the western US have been suggested to be influenced by local fire emissions (Jaffe et al., 2008; Jaffe, 2011) and from long-range transport of pollution from Siberian/Canadian fires (Jaffe et al., 2004). Our model indicates only a minor influence (not significant at the 0.05 level) of biomass burning emissions on summer $\mathrm{O}_{3}$ trends over the western US. The influence is somewhat more important in the low percentiles of the ozone distribution but still not significant during our study period. The low effect of biomass burning emissions in the model may be related to an underestimate in the model of boreal emission fires (especially those from large events) and of fire injection height (Generoso et al., 2007).

\subsection{Changes in stratospheric ozone}

Another plausible factor for changes in background $\mathrm{O}_{3}$ is related to changes in stratosphere-troposphere exchange. There are indications that $\mathrm{O}_{3}$ at mountain tops in Europe increase due to stratospheric input (Ordóñez et al., 2007; Tarasova et al., 2009). Furthermore, the transport of Asian pollution in the upper troposphere over the Pacific has been shown to be subject to mixing with lower stratospheric air in summertime (Liang et al., 2007).

The Synoz method developed by McLinden et al. (2000) as implemented in the GEOS-Chem model reproduces adequately the global-scale flux from the stratosphere to the troposphere but may underestimate stratospheric influence in regions of preferential downwelling and may not be appropriate to reproduce year-to-year changes in stratospheretroposphere exchange, as also reported in Koumoutsaris et al. (2008) (especially at several sites in the northern mid-latitudes). Hudman et al. (2004), for example, reported that the GEOS-Chem model underestimates the stratospheric contribution to $\mathrm{O}_{3}$ in the middle troposphere in spring over the Pacific.

\section{Conclusion}

In this paper, we compared simulated trends in daily maximum 8-h average summertime surface $\mathrm{O}_{3}$ concentrations with observations in Europe and the US. The observed $\mathrm{O}_{3}$ concentrations are decreasing at the high end of the probability distribution in the majority of the examined sites in both regions, which is very likely related to the decrease in local $\mathrm{O}_{3}$ precursor emissions. The model overestimates this decrease, which may be related to an overestimated decline in local emission inventories. In the model, the decrease in high $\mathrm{O}_{3}$ levels in Europe is also partly related to changes in a combination of meteorological parameters.

At the low percentiles, observations show larger variability in $\mathrm{O}_{3}$ trends even between nearby sites. There is however, in both regions, a marked change in the probability distribution with the high and low ends showing decreasing and increasing $\mathrm{O}_{3}$ concentrations, respectively. In particular, increasing trends are found in most of the sites in central Europe and western US at the low end of the distribution. This increase is probably related to an increase in the background $\mathrm{O}_{3}$ concentrations. These increasing trends are not captured in the model, except to a small extent at some sites in the western US. The reasons for discrepancies between observed and simulated ozone trends at low percentiles of the distribution may be related to the model's ability to reproduce the magnitude of $\mathrm{O}_{3}$ precursor emissions, the long-range transport events and the associated chemical processes, and changes in stratosphere-troposphere exchange. Using finer model (horizontal and vertical) resolution may contribute to an improved representation of background $\mathrm{O}_{3}$ in the GEOSChem model through a better representation of stratospheric and orographic influences (Zhang et al., 2011). However, several decades of integrations of a global, high-resolution model still require substantial amount of computer time. An alternative could be to use regional models which have been shown in some cases to improve performance in replicating $\mathrm{O}_{3}$ measurements and trends (Emery et al., 2012; Wilson et al., 2012). The definition of lateral boundary conditions (for both long-range and stratospheric $\mathrm{O}_{3}$ transport) remains however a key element, in particular to reproduce the lower percentiles of ozone distribution as reported in Hogrefe et al. (2011) and Emery (2012). Future global hindcast simulations should therefore seek to employ fully coupled stratospheretroposphere models, higher vertical and horizontal resolution, and to include improved regional emission scenarios in order to simulate accurately ozone trends. 


\section{Appendix A}

Table A1. Geographical information together with observed and simulated $\mathrm{O}_{3}$ trend values (in ppb per year) for the 5th and 95th percentiles for each site studied in Europe.

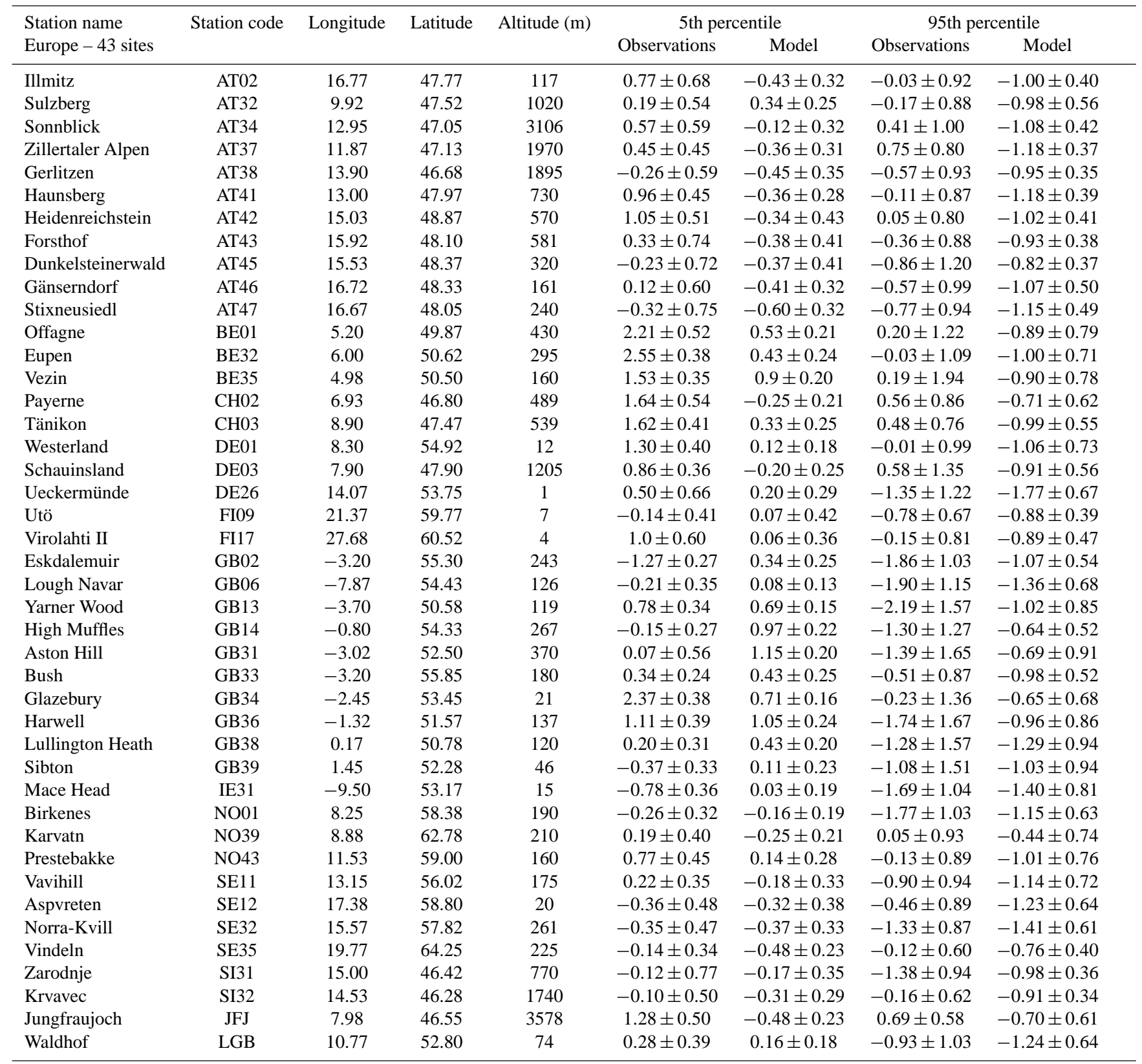


Table A2. Geographical information together with observed and simulated $\mathrm{O}_{3}$ trend values (in ppb per year) for the 5th and 95th percentiles for each site studied in the US.

\begin{tabular}{|c|c|c|c|c|c|c|c|c|}
\hline \multirow{2}{*}{$\begin{array}{l}\text { Station name } \\
\text { United States }-38 \text { sites }\end{array}$} & \multirow[t]{2}{*}{ Station code } & \multirow[t]{2}{*}{ Longitude } & \multirow[t]{2}{*}{ Latitude } & \multirow[t]{2}{*}{ Altitude (m) } & \multicolumn{2}{|c|}{ 5th percentile } & \multicolumn{2}{|c|}{ 95th percentile } \\
\hline & & & & & Observations & Model & Observations & Model \\
\hline Ambra & ALH157 & -89.62 & 38.87 & 164 & $-0.83 \pm 0.41$ & $-0.67 \pm 0.32$ & $-0.33 \pm 0.57$ & $-0.66 \pm 0.68$ \\
\hline Ann Arbor & ANA115 & -83.90 & 42.42 & 267 & $0.12 \pm 0.59$ & $-0.40 \pm 0.43$ & $-0.07 \pm 0.82$ & $-0.16 \pm 0.68$ \\
\hline Ashland & ASH135 & -68.41 & 46.60 & 235 & $-0.50 \pm 0.25$ & $0.06 \pm 0.20$ & $-1.11 \pm 0.64$ & $-0.15 \pm 0.40$ \\
\hline Beltsville & BEL116 & -76.82 & 39.03 & 46 & $-1.18 \pm 0.67$ & $-0.71 \pm 0.28$ & $-0.82 \pm 0.95$ & $-0.68 \pm 0.60$ \\
\hline Bondville & BVL130 & -88.37 & 40.05 & 212 & $-0.17 \pm 0.51$ & $-0.60 \pm 0.40$ & $-1.12 \pm 1.08$ & $-0.48 \pm 0.62$ \\
\hline Candor & CND125 & -79.84 & 35.26 & 198 & $-2.59 \pm 0.80$ & $-1.41 \pm 0.58$ & $-0.51 \pm 1.26$ & $-0.77 \pm 0.38$ \\
\hline Centennial & CNT169 & -106.24 & 41.36 & 3178 & $0.59 \pm 0.45$ & $-0.39 \pm 0.27$ & $0.63 \pm 0.71$ & $0.00 \pm 0.45$ \\
\hline Coweeta & COW137 & -83.43 & 35.06 & 686 & $-1.55 \pm 0.63$ & $-1.09 \pm 0.48$ & $0.03 \pm 0.90$ & $-0.58 \pm 0.47$ \\
\hline Connecticut Hill & СТН110 & -76.65 & 42.40 & 501 & $-0.71 \pm 0.33$ & $-0.28 \pm 0.31$ & $-1.06 \pm 0.79$ & $-0.43 \pm 0.61$ \\
\hline Coffeeville & CVL151 & -89.80 & 34.00 & 134 & $-1.22 \pm 0.36$ & $-0.85 \pm 0.28$ & $-0.48 \pm 1.06$ & $-0.81 \pm 0.47$ \\
\hline Deer Creek & DCP114 & -83.26 & 39.64 & 267 & $-0.50 \pm 0.64$ & $-0.42 \pm 0.42$ & $-0.74 \pm 0.83$ & $-0.37 \pm 0.59$ \\
\hline Kane Exp. Forest & KEF112 & -78.77 & 41.60 & 622 & $-1.74 \pm 0.43$ & $-0.36 \pm 0.31$ & $-0.92 \pm 0.65$ & $-0.32 \pm 0.63$ \\
\hline Laurel Hill & LRL117 & -79.25 & 39.99 & 615 & $-1.35 \pm 0.53$ & $-0.33 \pm 0.40$ & $-1.51 \pm 1.22$ & $-0.35 \pm 0.59$ \\
\hline Mackville & MCK131 & -85.05 & 37.70 & 353 & $-1.65 \pm 0.37$ & $-0.85 \pm 0.46$ & $-0.86 \pm 0.91$ & $-0.56 \pm 0.46$ \\
\hline M.K. Goddard & MKG113 & -80.15 & 41.43 & 384 & $-0.48 \pm 0.41$ & $-0.18 \pm 0.29$ & $-1.19 \pm 0.81$ & $-0.23 \pm 0.70$ \\
\hline Oxford & OXF122 & -84.73 & 39.53 & 284 & $-0.82 \pm 0.54$ & $-0.69 \pm 0.51$ & $-0.84 \pm 0.87$ & $-0.47 \pm 0.54$ \\
\hline Parsons & PAR107 & -79.66 & 39.09 & 510 & $-1.49 \pm 0.43$ & $-0.47 \pm 0.48$ & $-0.77 \pm 0.90$ & $-0.39 \pm 0.60$ \\
\hline Prince Edward & PED108 & -78.31 & 37.17 & 150 & $-1.44 \pm 0.52$ & $-1.01 \pm 0.52$ & $-1.21 \pm 0.90$ & $-0.80 \pm 0.45$ \\
\hline Pinedale & PND165 & -109.79 & 42.93 & 2388 & $1.19 \pm 0.62$ & $-0.48 \pm 0.25$ & $0.54 \pm 0.37$ & $-0.01 \pm 0.39$ \\
\hline Cranberry & PNF126 & -82.05 & 36.11 & 1219 & $-1.36 \pm 0.62$ & $-1.20 \pm 0.51$ & $-0.38 \pm 0.89$ & $-0.57 \pm 0.54$ \\
\hline Penn State & PSU106 & -77.93 & 40.72 & 378 & $-0.95 \pm 0.30$ & $-0.57 \pm 0.31$ & $-1.14 \pm 0.86$ & $-0.67 \pm 0.58$ \\
\hline Salamonie Reservoir & SAL133 & -85.66 & 40.82 & 250 & $-0.36 \pm 0.62$ & $-0.69 \pm 0.52$ & $-0.61 \pm 1.26$ & $-0.43 \pm 0.53$ \\
\hline Shenandoah NP - Big Mead & SHN418 & -78.43 & 38.52 & 1073 & $-0.39 \pm 0.69$ & $-1.45 \pm 0.49$ & $-0.61 \pm 0.91$ & $-0.87 \pm 0.40$ \\
\hline Speedwell & SPD111 & -83.83 & 36.47 & 361 & $-0.75 \pm 0.43$ & $-1.09 \pm 0.43$ & $-0.13 \pm 1.24$ & $-0.61 \pm 0.47$ \\
\hline
\end{tabular}


Acknowledgements. This work was supported by funding from the Swiss National Science Foundation under grant 200020-112231 and from the Swiss Federal Office for the Environment. The GEOS-Chem model is managed by the Atmospheric Chemistry Modeling group at Harvard University with support of the NASA Atmospheric Chemistry Modeling and Analysis Program. In addition, we are grateful to the World Data Center for Greenhouse Gases, the European Monitoring and Evaluation Program, and the Clean Air Status and Trends Network for providing the different set of data used in this study. This work contributes to the EU FP7 IP PEGASOS (FP7-ENV-2010/265148).

Edited by: P. Monks

\section{References}

Arino, O. and Melinotte, J. M.: Fire index atlas, Earth Obs. Quat., 50, 11-16, 1995.

Auvray, M. and Bey, I.: Long-range transport to Europe: Seasonal variations and implications for the European ozone budget, J. Geophys. Res.-Atmos., 110, 303-325, doi:10.1029/2004JD005503, 2005.

Benkovitz, C. M., Scholtz, M. T., Pacyna, J., Tarrason, L., Dignon, J., Voldner, E. C., Spiro, P. A., Logan, J. A., and Graedel, T. E.: Global gridded inventories of anthropogenic emissions of sulfur and nitrogen, J. Geophys. Res.-Atmos., 101, 29239-29253, 1996.

Bey, I., Jacob, D. J., Yantosca, R. M., Logan, J. A., Field, B. D., Fiore, A. M., Li, Q. B., Liu, H. G. Y., Mickley, L. J., and Schultz, M. G.: Global modeling of tropospheric chemistry with assimilated meteorology: Model description and evaluation, J. Geophys. Res.-Atmos., 106, 23073-23095, 2001.

Bousquet, P., Ciais, P., Miller, J. B., Dlugokencky, E. J., Hauglustaine, D. A., Prigent, C., Van der Werf, G. R., Peylin, P., Brunke, E. G., Carouge, C., Langenfelds, R. L., Lathiere, J., Papa, F., Ramonet, M., Schmidt, M., Steele, L. P., Tyler, S. C., and White, J.: Contribution of anthropogenic and natural sources to atmospheric methane variability, Nature, 443, 439-443, 2006.

Bronnimann, S., Buchmann, B., and Wanner, H.: Trends in nearsurface ozone concentrations in Switzerland: the 1990s, Atmos. Environ., 36, PII S1352-2310(02)00145-0, 2002.

Cristofanelli, P. and Bonasoni, P.: Background ozone in the southern Europe and Mediterranean area: Influence of the transport processes, Environ. Pollut., 157, 1399-1406, 2009.

Cui, J., Deolal, S. P., Sprenger, M., Henne, S., Staehelin, J., Steinbacher, M., and Nedelec, P.: Free tropospheric ozone changes over Europe as observed at Jungfraujoch (1990-2008): An analysis based on backward trajectories, J. Geophys. Res.-Atmos., 116, D10304, doi:10.1029/2010JD015154, 2011.

Duncan, B. N., Martin, R. V., Staudt, A. C., Yevich, R., and Logan, J. A.: Interannual and seasonal variability of biomass burning emissions constrained by satellite observations, J. Geophys. Res.-Atmos., 108, 4100, doi:10.1029/2002JD002378, 2003.

Duncan, B. N., Logan, J. A., Megretskaia, I. A., Yantosca, R. M., Novelli, P. C., Jones, N. B., and Rinsland, C. P.: The global budget of CO, 1988-1997: source estimates and validation with a global model, J. Geophys. Res.-Atmos., 112, D22301, doi:10.1029/2007JD008459, 2007.
EMEP: Fjaeraa, A. M., and A-G. Hjellbrekke, Ozone measurements 2006, EMEP/CCC-Report 2/2008, 0-7727, April 2008, available at: http://www.nilu.no/projects/ccc/reports/cccr4-2008.pdf, Tech. rep., Norwegian Meteorological institute, Norway, 2008.

Emery, C.: Modeling Uncertainties Related to Estimates of North American Background Ozone, Comments to EPA Clean Air Scientific Advisory Committee, Ozone Review Panel, in: Integrated Science Assessment for Ozone and Related Photochemical Oxidants, http://yosemite.epa.gov/SAB/SABPRODUCT.NSF/ 83B4A2CAD9001096852579800001CAAA/\$File/emery+oral+ statement.pdf, 2012.

Emery, C., Junga, J., Downeyb, N., Johnsona, J., Jimeneza, M., Yarwooda, G., and Morrisa, R.: Regional and global modeling estimates of policy relevant background ozone over the United States, Atmos. Env., 47, 206-217, 2012.

EPA: Cuideline on data handling conventions for the 8-hour ozone NAAQS, Tech. rep., US Environmental Protection Agency, Research Triangle Park, North Carolina, USA, 1998.

EPA: National air pollutant emission trends, 1990-1998, Rep. EPA454/R-00-002, Tech. rep., US Environmental Protection Agency, Research Triangle Park, NC, USA, 2000.

EPA: Latest Findings on National air quality - Status and Trends through 2006, available at http://www.epa.gov/air/airtrends/ 2007/, EPA-454/R-07-007, Tech. rep., US Environmental Protection Agency, Research Triangle Park, North Carolina, USA, 2007.

Fiore, A. M., Jacob, D. J., Bey, I., Yantosca, R. M., Field, B. D., Fusco, A. C., and Wilkinson, J. G.: Background ozone over the United States in summer: Origin, trend, and contribution to pollution episodes, Journal Of Geophys. Res.-Atmos., 107, 4275, doi:10.1029/2001JD000982, 2002.

Fiore, A. M., Dentener, F. J., Wild, O., Cuvelier, C., Schultz, M. G., Hess, P., Textor, C., Schulz, M., Doherty, R. M., Horowitz, L. W., MacKenzie, I. A., Sanderson, M. G., Shindell, D. T., Stevenson, D. S., Szopa, S., Van Dingenen, R., Zeng, G., Atherton, C., Bergmann, D., Bey, I., Carmichael, G., Collins, W. J., Duncan, B. N., Faluvegi, G., Folberth, G., Gauss, M., Gong, S., Hauglustaine, D., Holloway, T., Isaksen, I. S. A., Jacob, D. J., Jonson, J. E., Kaminski, J. W., Keating, T. J., Lupu, A., Marmer, E., Montanaro, V., Park, R. J., Pitari, G., Pringle, K. J., Pyle, J. A., Schroeder, S., Vivanco, M. G., Wind, P., Wojcik, G., Wu, S., and Zuber, A.: Multimodel estimates of intercontinental sourcereceptor relationships for ozone pollution, J. Geophys. Res.Atmos., 114, D04301, doi:10.1029/2008JD010816, 2009.

Frost, G. J., McKeen, S. A., Trainer, M., Ryerson, T. B., Neuman, J. A., Roberts, J. M., Swanson, A., Holloway, J. S., Sueper, D. T., Fortin, T., Parrish, D. D., Fehsenfeld, F. C., Flocke, F., Peckham, S. E., Grell, G. A., Kowal, D., Cartwright, J., Auerbach, N., and Habermann, T.: Effects of changing power plant $\mathrm{NO}_{x}$ emissions on ozone in the eastern United States: Proof of concept, J. Geophys. Res.-Atmos., 111, D12306, doi:10.1029/2005JD006354, 2006.

Generoso, S., Bréon, F.-M., Balkanski, Y., Boucher, O., and Schulz, M.: Improving the seasonal cycle and interannual variations of biomass burning aerosol sources, Atmos. Chem. Phys., 3, 12111222, doi:10.5194/acp-3-1211-2003, 2003.

Generoso, S., Bey, I., Attié, J.-L., and Bréon, F.-M.: A satelliteand model-based assessment of the 2003 Russian fires: Impact on the Arctic region, J. Geophys. Res.-Atmos., 112, D15302, 
doi:10.1029/2006JD008344, 2007.

Giglio, L., Randerson, J. T., van der Werf, G. R., Kasibhatla, P. S., Collatz, G. J., Morton, D. C., and DeFries, R. S.: Assessing variability and long-term trends in burned area by merging multiple satellite fire products, Biogeosciences, 7, 1171-1186, doi:10.5194/bg-7-1171-2010, 2010.

Herman, J. R., Bhartia, P. K., Torres, O., Hsu, C., Seftor, C., and Celarier, E.: Global distribution of UV-absorbing aerosols from Nimbus 7/TOMS data, J. Geophys. Res.-Atmos., 102, 1691116922, 1997.

Hogrefe, C., Hao, W., Zalewsky, E. E., Ku, J.-Y., Lynn, B., Rosenzweig, C., Schultz, M. G., Rast, S., Newchurch, M. J., Wang, L., Kinney, P. L., and Sistla, G.: An analysis of long-term regional-scale ozone simulations over the Northeastern United States: variability and trends, Atmos. Chem. Phys., 11, 567-582, doi:10.5194/acp-11-567-2011, 2011.

Hsu, N. C., Herman, J. R., Bhartia, P. K., Seftor, C. J., Torres, O., Thompson, A. M., Gleason, J. F., Eck, T. F., and Holben, B. N.: Detection of biomass burning smoke from TOMS measurements, Geophys. Res. Lett., 23, 745-748, 1996.

Hudman, R. C., Jacob, D. J., Cooper, O. R., Evans, M. J., Heald, C. L., Park, R. J., Fehsenfeld, F., Flocke, F., Holloway, J., Hubler, G., Kita, K., Koike, M., Kondo, Y., Neuman, A., Nowak, J., Oltmans, S., Parrish, D., Roberts, J. M., and Ryerson, T.: Ozone production in transpacific Asian pollution plumes and implications for ozone air quality in California, J. Geophys. Res.-Atmos., 109, D23S10, doi:10.1029/2004JD004974, 2004.

Hudman, R. C., Jacob, D. J., Turquety, S., Leibensperger, E. M., Murray, L. T., Wu, S., Gilliland, A. B., Avery, M., Bertram, T. H., Brune, W., Cohen, R. C., Dibb, J. E., Flocke, F. M., Fried, A., Holloway, J., Neuman, J. A., Orville, R., Perring, A., Ren, X., Sachse, G. W., Singh, H. B., Swanson, A., and Wooldridge, P. J.: Surface and lightning sources of nitrogen oxides over the United States: Magnitudes, chemical evolution, and outflow, J. Geophys. Res.-Atmos., 112, D12S06, doi:10.1029/2006JD007912, 2007.

IPCC: Aviation and the global atmosphere Joyce E. Penner, David H. Lister, David J. Griggs, David J. Dokken, Mack McFarland, Tech. rep., 1999.

IPCC: Summary for Policymakers. in: Climate Change 2007: The Physical Science Basis. Contribution of Working Group I to the Fourth Assessment Report of the Intergovernmental Panel on Climate Change, edited by: Solomon, S., Qin, D., Manning, M., Chen, Z., Marquis, M., Averyt, K. B., Tignor, M., and Miller, H. L., Tech. rep., 2007.

Jaffe, D.: Relationship between Surface and Free Tropospheric Ozone in the Western U.S., Environ. Sci. Technol., 45, 432-438, 2011.

Jaffe, D., Price, H., Parrish, D., Goldstein, A., and Harris, J.: Increasing background ozone during spring on the west coast of North America, Geophys. Res. Lett., 30, 1613, doi:10.1029/2003GL017024, 2003.

Jaffe, D., Bertschi, I., Jaegle, L., Novelli, P., Reid, J. S., Tanimoto, H., Vingarzan, R., and Westphal, D. L.: Long-range transport of Siberian biomass burning emissions and impact on surface ozone in western North America, Geophys. Res. Lett., 31, L16106, doi:10.1029/2004GL020093, 2004.

Jaffe, D., Chand, D., Hafner, W., Westerling, A., and Spracklen, D.: Influence of fires on $\mathrm{O}_{3}$ concentrations in the western US, Environ. Sci. Technol., 42, 5885-5891, 2008.
Jenkin, M. E.: Trends in ozone concentration distributions in the UK since 1990: Local, regional and global influences, Atmos. Environ., 42, 5434-5445, 2008.

Jonson, J. E., Simpson, D., Fagerli, H., and Solberg, S.: Can we explain the trends in European ozone levels?, Atmos. Chem. Phys., 6, 51-66, doi:10.5194/acp-6-51-2006, 2006.

Kiley, C. M., Fuelberg, H. E., Palmer, P. I., Allen, D. J., Carmichael, G. R., Jacob, D. J., Mari, C., Pierce, R. B., Pickering, K. E., Tang, Y. H., Wild, O., Fairlie, T. D., Logan, J. A., Sachse, G. W., Shaack, T. K., and Streets, D. G.: An intercomparison and evaluation of aircraft-derived and simulated $\mathrm{CO}$ from seven chemical transport models during the TRACE-P experimentras, J. Geophys. Res.-Atmos., 108, 8819, doi:10.1029/2002JD003089, 2003.

Kim, S. . W., Heckel, A., Frost, G. J., Richter, A., Gleason, J., Burrows, J. P., McKeen, S., Hsie, E. . Y., Granier, C., and Trainer, M.: $\mathrm{NO} 2$ columns in the western United States observed from space and simulated by a regional chemistry model and their implications for $\mathrm{NO}_{\mathrm{x}}$ emissions, J. Geophys. Res.-Atmos., 114, D11301, doi:10.1029/2008JD011343, 2009.

Kim, S. W., Heckel, A., McKeen, S. A., Frost, G. J., Hsie, E. Y., Trainer, M. K., Richter, A., Burrows, J. P., Peckham, S. E., and Grell, G. A.: Satellite-observed US power plant $\mathrm{NO}_{\mathrm{x}}$ emission reductions and their impact on air quality, Geophys. Res. Lett., 33, L22812, doi:10.1029/2006GL027749, 2006.

Koumoutsaris, S., Bey, I., Generoso, S., and Thouret, V.: Influence of El Niño-Southern Oscillation on the interannual variability of tropospheric ozone in the northern midlatitudes, J. Geophys. Res.-Atmos., 113, D19301, doi:10.1029/2007JD009753, 2008.

Kurokawa, J.-i., Yumimoto, K., Uno, I., and Ohara, T.: Adjoint inverse modeling of $\left.\mathrm{NO}_{(} \mathrm{x}\right)$ emissions over eastern China using satellite observations of $\mathrm{NO}_{(2)}$ vertical column densities, Atmos. Environ., 43, 1878-1887, 2009.

Liang, Q., Jaegle, L., Hudman, R. C., Turquety, S., Jacob, D. J., Avery, M. A., Browell, E. V., Sachse, G. W., Blake, D. R., Brune, W., Ren, X., Cohen, R. C., Dibb, J. E., Fried, A., Fuelberg, H., Porter, M., Heikes, B. G., Huey, G., Singh, H. B., and Wennberg, P. O.: Summertime influence of Asian pollution in the free troposphere over North America, J. Geophys. Res.-Atmos., 112, D12S11, doi:10.1029/2006JD007919, 2007.

Lin, C. Y. C., Jacob, D. J., Munger, J. W., and Fiore, A. M.: Increasing background ozone in surface air over the United States, Geophys. Res. Lett., 27, 3465-3468, 2000.

Liu, H. Y., Jacob, D. J., Bey, I., Yantosca, R. M., Duncan, B. N., and Sachse, G. W.: Transport pathways for Asian pollution outflow over the Pacific: interannual and seasonal variations, J. Geophys. Res.-Atmos., 108, 8786, doi:10.1029/2002JD003102, 2003.

Lobert, J. M., Keene, W. C., Logan, J. A., and Yevich, R.: Global chlorine emissions from biomass burning: Reactive Chlorine Emissions inventory, J. Geophys. Res.-Atmos., 104, 8373-8389, 1999.

Logan, J., Staehelin, J., Megretskaia, I.a. nd Cammas, J.-P., Thouret, V., Claude, H., De Backer, H., Steinbacher, M., Scheel, H.E., Stübi, R., Fröhlich, M., and R., D.: Changes in ozone over Europe: Analysis of ozone measurements from sondes, regular aircraft (MOZAIC) and alpine surface sites, J. Geophys. Res.Atmos., 117, D09301, doi:10.1029/2011JD016952, 2012.

Logan, J. A., Schultz, M., and Oltmans, S.: Observing and Understanding Tropospheric Ozone Changes, EOS 
Transactions American Geophysical Union, 91, p. 119, doi:10.1029/2010EO130004, 2010.

Martien, P. T. and Harley, R. A.: Adjoint sensitivity analysis for a three-dimensional photochemical model: Application to Southern California, Environ. Sci. Technol., 40, 4200-4210, 2006.

McLinden, C. A., Olsen, S. C., Hannegan, B., Wild, O., Prather, M. J., and Sundet, J.: Stratospheric ozone in 3-D models: A simple chemistry and the cross-tropopause flux, J. Geophys. Res.Atmos., 105, 14653-14665, 2000.

Naja, M., Akimoto, H., and Staehelin, J.: Ozone in background and photochemically aged air over central Europe: Analysis of longterm ozonesonde data from Hohenpeissenberg and Payerne, J. Geophys. Res.-Atmos., 108, 4063, doi:10.1029/2002JD002477, 2003.

Ohara, T., Akimoto, H., Kurokawa, J., Horii, N., Yamaji, K., Yan, X., and Hayasaka, T.: An Asian emission inventory of anthropogenic emission sources for the period 1980-2020, Atmos. Chem. Phys., 7, 4419-4444, doi:10.5194/acp-7-4419-2007, 2007.

Ohara, T., Yamaji, K., Uno, I., Tanimoto, H., Sugata, S., Nagashima, T., Kurokawa, J. I., Horii, N., and Alkimoto, H.: Long-term simulations of surface ozone in east Asia during 1980-2020 with CMAQ and REAS inventory, Air Pollut. Model. Appl., XIX, 136-144, 2008.

Oltmans, S. J., Lefohn, A. S., Harris, J. M., Galbally, I., Scheel, H. E., Bodeker, G., Brunke, E., Claude, H., Tarasick, D., Johnson, B. J., Simmonds, P., Shadwick, D., Anlauf, K., Hayden, K., Schmidlin, F., Fujimoto, T., Akagi, K., Meyer, C., Nichol, S., Davies, J., Redondas, A., and Cuevas, E.: Long-term changes in tropospheric ozone, Atmos. Environ., 40, 3156-3173, 2006.

Ordóñez, C., Brunner, D., Staehelin, J., Hadjinicolaou, P., Pyle, J. A., Jonas, M., Wernli, H., and Prevot, A. S. H.: Strong influence of lowermost stratospheric ozone on lower tropospheric background ozone changes over Europe, Geophys. Res. Lett., 34, L07805, doi:10.1029/2006GL029113, 2007.

Parrish, D. D.: Critical evaluation of US on-road vehicle emission inventories, Atmos. Environ., 40, 2288-2300, 2006

Piccot, S. D., Watson, J. J., and Jones, J. W.: A global inventory of volatile organic-compound emissions from anthropogenic sources, J. Geophys. Res.-Atmos., 97, 9897-9912, 1992.

Pickering, K. E., Wang, Y. S., Tao, W. K., Price, C., and Muller, J. F.: Vertical distributions of lightning $\mathrm{NO}_{x}$ for use in regional and global chemical transport models, J. Geophys. Res.-Atmos., 103, 31203-31216, 1998.

Price, C. and Rind, D.: A simple lightning parameterization for calculating global lightning distributions, J. Geophys. Res.-Atmos., 97, 9919-9933, 1992.

Rastigejev, Y., Park, R., Brenner, M. P., and Jacob, D. J.: Resolving intercontinental pollution plumes in global models of atmospheric transport, J. Geophys. Res.-Atmos., 115, D02302, doi:10.1029/2009JD012568, 2010.

Rigby, M., Prinn, R. G., Fraser, P. J., Simmonds, P. G., Langenfelds, R. L., Huang, J., Cunnold, D. M., Steele, L. P., Krummel, P. B., Weiss, R. F., O'Doherty, S., Salameh, P. K., Wang, H. J., Harth, C. M., Muhle, J., and Porter, L. W.: Renewed growth of atmospheric methane, Geophys. Res. Lett., 35, L22805, doi:10.1029/2008GL036037, 2008.

Schär, C., Vidale, P. L., Luthi, D., Frei, C., Haberli, C., Liniger, M. A., and Appenzeller, C.: The role of increasing temperature variability in European summer heatwaves, Nature, 427, 332336, 2004.

Sillman, S.: Evaluation of observation-based methods for analyzing ozone production and ozone- $\mathrm{NO}_{x}$-VOC sensitivity, Tech. rep., US Environmental Protection Agency, Research Triangle Park, NC, USA, 2002.

Simmonds, P. G., Manning, A. J., Derwent, R. G., Ciais, P., Ramonet, M., Kazan, V., and Ryall, D.: A burning question. Can recent growth rate anomalies in the greenhouse gases be attributed to large-scale biomass burning events?, Atmos. Environ., 39, 2513-2517, 2005.

Staehelin, J. and Weiss, A. K.: Swiss history of atmospheric ozone research and results of long-term Swiss ozone measurements, Ozone Sci. Eng., 23, 461-466, 2001.

Tarasova, O. A., Senik, I. A., Sosonkin, M. G., Cui, J., Staehelin, J., and Prévôt, A. S. H.: Surface ozone at the Caucasian site Kislovodsk High Mountain Station and the Swiss Alpine site Jungfraujoch: data analysis and trends (1990-2006), Atmos. Chem. Phys., 9, 4157-4175, doi:10.5194/acp-9-4157-2009, 2009.

Torres, O., Bhartia, P. K., Herman, J. R., Ahmad, Z., and Gleason, J.: Derivation of aerosol properties from satellite measurements of backscattered ultraviolet radiation: Theoretical basis, J. Geophys. Res.-Atmos., 103, 17099-17110, 1998.

Uno, I., He, Y., Ohara, T., Yamaji, K., Kurokawa, J.-I., Katayama, M., Wang, Z., Noguchi, K., Hayashida, S., Richter, A., and Burrows, J. P.: Systematic analysis of interannual and seasonal variations of model-simulated tropospheric $\mathrm{NO}_{2}$ in Asia and comparison with GOME-satellite data, Atmos. Chem. Phys., 7, 16711681, doi:10.5194/acp-7-1671-2007, 2007.

Vestreng, V., Rigler, E., Adams, M., Kindbom, K., Pacyna, J. M., Denier van der Gon, H., Reis, S., and Travnikov, O.: Inventory review 2006, Emission data reported to LRTAP and NEC Directive, Stage 1, 2 and 3 review and Evaluation of Inventories of HM and POPs. EMEP/MSC-W Technical Report 1/2006 ISSN 1504-6179, available at: http://www.emep.int/, Tech. rep., EMEP/MSC-Wy, 2006.

Vingarzan, R.: A review of surface ozone background levels and trends, Atmos. Environ., 38, 3431-3442, 2004.

Wang, H., Jacob, D. J., Le Sager, P., Streets, D. G., Park, R. J., Gilliland, A. B., and van Donkelaar, A.: Surface ozone background in the United States: Canadian and Mexican pollution influences, Atmos. Environ., 43, 1310-1319, 2009.

Wang, Y. H., Jacob, D. J., and Logan, J. A.: Global simulation of tropospheric $\mathrm{O}_{3}-\mathrm{NO}_{\mathrm{x}}$-hydrocarbon chemistry - 1. Model formulation, J. Geophys. Res.-Atmos., 103, 10713-10725, 1998a.

Wang, Y. H., Logan, J. A., and Jacob, D. J.: Global simulation of tropospheric $\mathrm{O}_{3}-\mathrm{NO}_{x}$-hydrocarbon chemistry - 2. Model evaluation and global ozone budget, J. Geophys. Res.-Atmos., 103, 10727-10755, 1998b.

Wilson, R. C., Fleming, Z. L., Monks, P. S., Clain, G., Henne, S., Konovalov, I. B., Szopa, S., and Menut, L.: Have primary emission reduction measures reduced ozone across Europe? An analysis of European rural background ozone trends 1996-2005, Atmos. Chem. Phys., 12, 437-454, doi:10.5194/acp-12-437-2012, 2012.

WMO: WMO WDCGG DATA SUMMARY, WDCGG No.32, GAW data, Volume IV-Grennhouse gases and Other Atmospheric Gases, Published by Japan Meteorological Agency 
in co-operation with World Meteorological Organisation, available at: http://gaw.kishou.go.jp/wdcgg/products/summary/ sum32/sum32contents.html., Tech. rep., World Meteorological Organization, Geneva, Switzerland, 2008.

Wuebbles, D. J. and Hayhoe, K.: Atmospheric methane and global change, Earth-Science Reviews, 57, PII S0012-8252(01)000629, 2002.

Xu, X., Lin, W., Wang, T., Yan, P., Tang, J., Meng, Z., and Wang, Y.: Long-term trend of surface ozone at a regional background station in eastern China 1991-2006: enhanced variability, Atmos. Chem. Phys., 8, 2595-2607, doi:10.5194/acp-8-2595-2008, 2008.

Yienger, J. J. and Levy, H.: Empirical-model of global soil-biogenic $\mathrm{NO}_{\mathrm{x}}$ emissions, J. Geophys. Res.-Atmos., 100, 11447-11464, 1995.

Zellweger, C., Ammann, M., Buchmann, B., Hofer, P., Lugauer, M., Ruttimann, R., Streit, N., Weingartner, E., and Baltensperger, U.: Summertime $\mathrm{NO}_{\mathrm{y}}$ speciation at the Jungfraujoch, $3580 \mathrm{~m}$ above sea level, Switzerland, J. Geophys. Res.-Atmos., 105, 6655$6667,2000$.
Zhang, L., Jacob, D. J., Boersma, K. F., Jaffe, D. A., Olson, J. R., Bowman, K. W., Worden, J. R., Thompson, A. M., Avery, M. A., Cohen, R. C., Dibb, J. E., Flock, F. M., Fuelberg, H. E., Huey, L. G., McMillan, W. W., Singh, H. B., and Weinheimer, A. J.: Transpacific transport of ozone pollution and the effect of recent Asian emission increases on air quality in North America: an integrated analysis using satellite, aircraft, ozonesonde, and surface observations, Atmos. Chem. Phys., 8, 6117-6136, doi:10.5194/acp-8-6117-2008, 2008.

Zhang, L., Jacob, D. J., Downey, N. V., Wood, D. A., Blewitt, D., Carouge, C. C., van Donkelaar, A., Jones, D. B. A., Murray, L. T., and Wang, Y.: Improved estimate of the policy-relevant background ozone in the United States using the GEOS-Chem global model with $1 / 2$ degrees $\times 2 / 3$ degrees horizontal resolution over North America, Atmos. Environ., 45, 6769-6776, 2011. 